Tersedia online di http://ejournal-balitbang.kkp.go.id/index.php/jp
e-mail:jurnalpari@gmail.com
Jurnal Pari
Volume 2 Nomor 2 Desember 2016
p-ISSN : 2502-0730
e-ISSN : 2549-0133

\title{
ANALISIS KEPUASAN PEMUSTAKA TERHADAP PELAYANAN PERPUSTAKAAN PUSAT PENELITIAN DAN PENGEMBANGAN PERIKANAN BUDIDAYA
}

\section{ANAL YSIS VISITORS' SATISFACTION ON SERVICE OF AQUACULTURE FISHERIES FOR DEVELOPMENT AND RESEARCH CENTER LIBRARY}

\author{
Erny Puspa \\ Pusat Penelitian dan Pengembangan Perikanan Budidaya \\ Diterima tanggal : 30 Agustus 2016 Diterima setelah perbaikan : 10 Oktober 2016 \\ disetujui terbit : 31 Oktober 2016
}

\begin{abstract}
ABSTRAK
Penelitian ini bertujuan untuk mengetahui tingkat kepuasan pemustaka terhadap pelayanan pada perpustakaan Pusat Penelitian dan Pengembangan Perikanan Budidaya. Variabel penelitian terdiri dari koleksi, sirkulasi, tenaga perpustakaan, sarana dan prasarana perpustakaan. Metode penelitian menggunakan deskriptif kuantitatif dengan teknik pengumpulan data melalui observasi, studi pustaka dan angket. Sampel terdiri 40 resonden, teknik pengambilan sampling dilakukan secara accidental. Analisis pengukuran data menggunakan skala likert dengan penghitungan skor. Hasil penelitian menunjukkan bahwa pada tingkat kepuasan terhadap koleksi diperoleh skor rata rata 2,92 (cukup puas), pada tingkat kepuasan terhadap layanan perpustakaan diperoleh skor rata rata 3.30 (cukup puas), pada tingkat kepuasan terhadap petugas perpustakaan diperoleh skor rata rata 3.64 (puas) dan pada tingkat kepuasan sarana prasarana diperoleh skor rata rata 3.38 (cukup puas). Hasil rekapitulasi semua variabel diperoleh skor 3.31 berada pada skala interval 2.62-3.42 menunjukkan hasil kepuasan pemustaka terhadap pelayanan perpustakaan Pusat Penelitian dan Pengembangan Perikanan Budidaya cukup memuaskan
\end{abstract}

Kata Kunci : kepuasan pemustaka, pelayanan perpustakaan, analisis kepuasan

\section{ABSTRACT}

The purpose of this research is to know the visitors' satisfaction level of Puslitbangkan Budidaya library services. Research consist of collection, circulation, Library workers, and Library's facilities and infrastructures. The research method is Descriptive Quantitative with data collection techniques through observations, literature review and questionnaires. Samples consist of 40 respondent, sampling techniques are done accidentally. Data measurement is using Likert scale with score calculations. The result for visitors' satisfactions of library's collection is 2,92 (adequately content). The result for visitors' satisfaction to library's circulation service is 3,3 (adequate). The result for visitors' satisfaction of library's worker is 3,5 and visitors' satisfaction of library's facilities and infrastructures is 3.64 (adequate). Recapitulation result of all the variables is 3.32 within the scale 2.62-3.42 intervals shows library's visitors' satisfaction to Puslitbangkan Budidaya library services is adequate

Keywords : Visitors' satisfaction, library services, satisfactory analysis.

Korespondensi Penulis :

Gedung Balitbang II, JI. Pasir Putih II, Ancol Timur, Jakarta Utara 14430

Email : erny.puslitbangkan@gmail.com 


\section{PENDAHULUAN}

Perpustakaan Pusat Penelitian dan Pengembangan Perikanan Budidaya (Puslitbangkan Budidaya) merupakan perpustakaan khusus, Perpustakaan khusus adalah perpustakaan yang diselenggarakan oleh lembaga atau instansi negara, pemerintah, pemerintah daerah ataupun lembaga atau instansi swasta yang layanannya diperuntukkan bagi pengguna di lingkungan lembaga atau instansi yang bersangkutan (Hasugian, 2009 : 81)

Tugas utama perpustakaan khusus adalah menyediakan layanan informasi yang mencakup: layanan referensi, layanan penelusuran dan temu kembali informasi, layanan sirkulasi, konsultasi bibliografi, penyediaan fasilitas membaca/belajar yang nyaman. Selain itu perpustakaan harus pula menyediakan layanan pendidikan pemakai untuk meningkatkan wawasan dan keterampilan pemustaka dalam menggunakan layanan, koleksi, dan fasilitas pendukung perpustakaan, khususnya pemanfaatan teknologi informasi dan komunikasi

Barometer keberhasilan perpustakaan adalah dapat memberikan pelayanan yang berkualitas, tepat guna, hal ini sangat dipengaruhi oleh prosedur prosedur didalam perpustakaan tersebut sehingga dapat memberikan pelayanan terbaik. Berdasarkan International Organization for Standardization atau ISO 11620-1998, kepuasan pengguna menempati urutan pertama dari 29 indikator untuk pengukuran kinerja perpustakaan. Adapun faktor kepuasan pemustaka pada perpustakaan diukur dari keberhasilan perpustakaan dalam memberikan pelayanan yang baik dan berkualitas bagi pemustakanya, dalam hal ini terdapat empat kriteria agar perpustakaan menjadi lebih baik dan bekualitas sebagaimana dikemukakan oleh $M$. Juran dalam Tjiptono (2002:11) yaitu kecepatan dalam memberikan pelayanan, ketepatan dalam memenuhi kebutuhan masyarakat, keramahan petugas dalam menghadapi masyarakat serta kenyamanan tempat pelayanan. Dengan kata lain, perpustakaan sebagai pusat informasi harus selalu siap memberi pelayanan yang terbaik sehingga dapat memberikan kepuasan kepada pemustakanya.

Berkaitan dengan uraian tersebut diatas penulis berkeinginan mengetahui tingkat kepuasan pemustaka pada pelayanan di perpustakaan Puslitbangkan Budidaya. Hal ini berdasarkan pengamatan penulis dengan semakin menurunnya pemustaka yang datang ke perpustakaan berdasar alasan inilah penulis mengadakan penelitian dengan judul "Analisis kepuasan pemustaka terhadap pelayanan perpustakaan Pusat Penelitian dan Pengembangan Perikanan Budidaya

\section{TINJAUAN PUSTAKA}

\section{Perpustakaan Khusus}

\section{Pengertian Perpustakaan Khusus}

Perpustakaan merupakan sumber informasi dimana pemustaka dapat memenuhi sumber ilmu pengetahuan dari sumber informasi yang tersedia disana. Menurut Undang-undang Perpustakaan No. 43 Tahun 2007, perpustakaan khusus adalah Perpustakaan yang diperuntukkan secara terbatas bagi pemustaka di lingkungan lembaga pemerintah, lembaga masyarakat, lembaga pendidikan keagamaan, rumah ibadah, atau organisasi lain (Perpustakaan Nasional RI 2007). Sedangkan menurut Badan Standardisasi Nasional (SNI 7496, 2009, hlm.2) menyebutkan:

Perpustakaan khusus adalah institusi/unit kerja pengelola karya tulis, karya cetak, dan karya rekam yang dikelola secara profesional berdasarkan sistem yang baku untuk mendukung kelancaran/keberhasilan pencapaian visi, misi dan tujuan instansi induk yang menaunginya.

Menurut Hasugian (2009:81), perpustakaan khusus adalah perpustakaan yang diselenggarakan oleh lembaga atau instansi negara, pemerintah, pemerintah daerah ataupun lembaga atau instansi swasta yang layanannya diperuntukkan bagi pengguna di lingkungan lembaga atau instansi yang bersangkutan. 
Dari pengertian di atas maka dapat disimpulkan perpustakaan khusus adalah perpustakaan yang diselenggarakan oleh lembaga pemerintah, ataupun swasta dimana pelayanannya diperuntukkan bagi lingkungan lembaga tersebut.

\section{Tujuan Perpustakaan Khusus}

Tujuan perpustakaan secara umum menurut Sutarno NS (2006 : 53) adalah menghimpun, menyediakan, mengolah, memelihara, dan mendayagunakan semua koleksi bahan pustaka, menyediakan sarana pemanfaatannya, dan melayani masyarakat pengguna, yang membutuhkan informasi dan bahan bacaan. Tujuan perpustakaan khusus menurut Hasugian (2009 : 82) adalah perpustakaan yang hanya menyediakan koleksi khusus yang berkaitan dengan misi dan tujuan dari organisasi atau lembaga yang memilikinya dan biasanya hanya memberikan pelayanan yang khusus hanya kepada staf organisasi atau lembaganya saja.

\section{Karateristik Perpustakaan Khusus}

Perpustakaan khusus biasanya juga mempunyai karakteristik khusus dilihat dari fungsi, subyek yang ditangani, koleksi yang dikelola, pengguna yang dilayani, dan kedudukannya. Beberapa hal ciri-ciri perpustakaan khusus menurut Sulistiyo Basuki (1993)

a. Memiliki buku yang terbatas pada satu atau beberapa disiplin ilmu saja.

b. Keanggotaan perpustakaan terbataspada sejumlah anggota yang ditentukan oleh kebijakan perpustakaan atau kebijakan badan induk tempat perpustakaan tersebut bernaung.

c. Peran utama pustakawan ialah melakukan penelitian kepustakaan untuk anggota.

d. Tekanan koleksi bukan pada buku (dalam arti sempit) melainkan pada majalah, pamphlet,paten, laporan penelitian, abstrak, atau indeks yang informasinya lebih mutakhir dibandingkan buku.

e. Jasa yang diberikan lebih mengarah kepada minat anggota perorangan.

\section{Pelayanan Perpustakaan}

Pelayanan perpustakaan merupakan kunci keberhasilan suatu perpustakaan. karena pada pelayanan perpustakaan terjadi hubungan langsung antara pustakawan dan pemustaka sebagai sarana penyebaran informasi serta pemanfaatan jasa dan fasilitas yang ada di perpustakaan

Pelayanan perpustakaan menurut Darmono (2001:34), bahwa definisi layanan perpustakaan adalah Suatu layanan yang menawarkan semua bentuk koleksi yang dimiliki perpustakaan kepada pemakai yang datang ke perpustakaan dan meminta informasi yang dibutuhkannya. Dalam hali ini perpustakaan merupakan tempat terjadinya interaksi antara pustakawan yang membutuhakan pelayanan pustakawan.

Menurut Sutarno (2006: 90) bahwa layanan perpustakaan merupakan salah satu kegiatan utama disetiap perpustakaan dimana layanan tersebut merupakan kegiatan yang langsung berhubungan dengan masyarakat dan sekaligus merupakan barometer keberhasilan perpustakaan. Pelayanan perpustakaan merupakan kegiatan yang memberikan layanan yang baik sebagaimana dikehendaki oleh pemakai dalam pemberiaan informasi.

Dalam arti lain layanan perpustakaan merupakan jasa pemberian informasi kepada pemustaka secara cepat dan tepat kepada masyarakat pemustaka. Adapun jenis layanan /jasa perpustakaan sebagai berikut

Jenis-jenis layanan perpustakaan

Menurut Buku Pedoman Umum Penyelenggaraan Perpustakaan Umum (2000: 37) pelayanan kepada masyarakat meliputi kegiatan sebagai berikut :

1. Menyusun rencana operasional pelayanan informasi

2. Layanan sirkulasi

3. Layanan perpustakaan keliling

4. Layanan rujukan

5. Penelusuran literatur

6. Layanan bahan pandang dengar

7. Menyediakan bahan pustaka

8. Bimbingan membaca

9. Bimbingan pemakai perpustakaan

10. Bercerita kepada anak-anak 
11. Membina kelompok pembaca

12. Menyebarkan informasi terbaru/ kilat

13. Menyebarkan informasi terseleksi

14. Membuat analisis kepustakaan

15. Membuat statistik pelayanan informasi kepada masyarakat.

\section{Sistim Pelayanan Perpustakaan}

Dalam mengelola perpustakaan diperlukan sistem yang jelas, sistem perpustakaan menurut menurut Pedoman Umum Pengelolaan Koleksi Perpustakaan Perguruan Tinggi (1999: 33) sistem layanan perpustakaan yang dikenal ada 2 (dua) yaitu: Sistem layanan terbuka (opened acces) dan sistem layanan tertutup (closed acces).

Sistim Pelayan terbuka dan tertutup menurut Darmono (2001 : 137) Sistim Pelayanan terbuka adalah sistem layanan yang memungkinkan para pemustaka secara langsung dapat memilih, menemukan, dan mengambil sendiri bahan pustaka yang dikehendaki dari jajaran koleksi perpustakaan sedangkan sistem layanan tertutup adalah sistem layanan perpustakaan yang tidak memungkinkan pemakai perpustakaan mengambil sendiri bahan pustaka diperpustakaan.

\section{Pemustaka}

Pemustaka adalah pengguna perpustakaan yaitu perseorangan, kelompok orang, masyarakat, atau lembaga yang memanfaatkan fasilitas layanan perpustakaan. Pemustaka dapat diartikan juga sebagai orang-orang yang datang ke perpustakaan dengan maksud, tujuan, harapan tertentu serta ingin memperoleh apa yang diinginkan dengan cara yang menyenangkan. Dalam Undang-Undang Republik Indonesia Nomor 43 Tahun 2007, disebutkan pemustaka adalah pengguna perpustakaan yaitu perseorangan, kelompok orang, masyarakat, atau lembaga yang memanfaatkan fasilitas layanan perpustakaan. Sedangkan menurut Suwarno, W (2009:80) pemustaka ialah pengguna fasilitas yang disediakan perpustakaan, baik koleksi maupun buku (bahan pustaka maupun fasilitas lainnya). Ada berbagai jenis pemustaka seperti pelajar, mahasiswa, guru, dosen, karyawan dan masyarakat umum, tergantung dengan jenis perpustakaan tersebut.

Pemustaka dalam penelitian ini adalah seluruh pemustaka yang memanfaatkan jasa perpustakaan Puslitbangkan Budidaya, baik untuk kepentingan penelitian, pendidikan, penambahan informasi maupun untuk sekedar rekreasi.

\section{Kepuasan Pemustaka}

Kepuasan Pemustaka merupakan parameter keberhasilan suatu perpustakaan. Berdasarkan International Organizatin for Standardization atau ISO 11620-1998, kepuasan pengguna menempati urutan pertama dari 29 indikator untuk pengukuran kinerja perpustakaan (Purnomowati : 2000).

Definisi Kepuasan menurut Day dalam Tjiptono (1996:146) bahwa kepuasan atau ketidakpuasan adalah respon terhadap evaluasi ketidaksesuaian/diskonfirmasi yang dirasakan antara harapan sebelumnya (atau norma kinerja lainnya) dan kinerja aktual produk yang dirasakan setelah pemakaiannya. Menurut pakar pemasaran Kotler (1999:52) kepuasan adalah tingkat perasaan seseorang setelah membandingkan kinerja (atau hasil) yang dia rasakan dibandingkan dengan harapannya.

Dalam hal ini dapat disimpulkan kepuasan pada perpustakaan adalah dapat memberikan pelayanan yang baik terhadap pemustaka sebagaimana menurut Zulfikar Zen (2006:90) Layanan yang baik adalah layanan yang dapat memberikan rasa senang dan puas kepada pemakai.

Pelayanan yang baik, cepat dan tepat memberi nilai tambah bagi pemustaka yang berkunjung ke perpustakaan, menurut Soeatminah (1992: 17), pelayanan dikatakan baik apabila dilakukan dengan:

(1) cepat, artinya untuk memperoleh layanan, orang tidak perlu menunggu terlalu lama,

(2) tepat waktu, artinya orang dapat memperoleh kebutuhan tepat pada waktunya

(3) benar, artinya pustakawan membantu perolehan sesuatu sesuai dengan yang diinginkan. 
Demikian pula menurut Riyanto (2004:16) perpustakaan dapat dikatakan baik dan berkualitas harus memiliki beberapa kriteria yaitu (a) koleksi relevan, aktual dan akurat; (b) tenaga yang berkualitas dan profesional; (c) sistem pelayanan yang cepat dan tepat; dan (d) didukung oleh sarana dan prasarana yang memadai. Serta perpustakaan dapat dikatakan berhasil jika perpustakaan itu dapat dimanfaatkan secara optimal oleh penggunanya dan keberhasilannya menunjukkan bahwa perpustakaan tersebut dikelola oleh orang yang memiliki kemampuan manajemen yang baik serta pegguna merasa puas terhadap layanannya.

Dalam hal ini dapat disimpulkan bahwa faktor faktor yang mempengaruhi kepemuasan pelayanan perpustakaan adalah fasilitas, koleksi, jasa layanan yang tersedia, sumberdaya manusia, dan peraturan dan tata tertib perpustakaan.

\section{METODE PENELITIAN}

Metode penelitian menggunakan deskriptif kuantitatif, data diperoleh dari hasil observasi, studi pustaka dan penyebaran kuiesioner. Subyek penelitian adalah 40 pemustaka yang berkunjung ke perpustakaan. Sampel diambil sebanyak 40 responden yang terdiri 27 mahasiswa, 8 peneliti dan 5 karyawan. Menurut Arikunto (2002, hlm. 112) mengemukakan bahwa jika subjeknya kurang dari 100 lebih baik diambil semua sehingga penelitian merupakan penelitian populasi. Jika jumlahnya besar dapat diambil $10-15 \%$ atau $20-25 \%$. Teknik pengambilan sampel dilakukan melalui teknik accidental. Data kuantitatif kemudian diolah dan ditentukan secara persentase Sudijono (1991, hlm.40) dan pengukuran data metode skala likert, dengan rumus rumus sebagai berikut:

a. Persentase

$$
P=\frac{F}{N} \times 100 \%
$$

Keterangan :

$$
\begin{array}{lll}
\mathrm{P} & : & \text { Persentase } \\
\mathrm{F} & : & \text { Frekwensi jawaban responden } \\
\mathrm{N} & : & \text { Sample yang diolah }
\end{array}
$$

b. Pengukuran data skala likert

Metode pengukuran data menggunakan Skala Likert dengan pilihan jawaban sebagai berikut :

STP : Sangat Tidak Puas (1)

TP : Tidak Puas (2)

$\mathrm{CP}$ : Cukup Puas (3)

$P$ : Puas (4)

SP : Sangat Puas (5)

Menentukan skor rata rata

$$
\begin{array}{ll}
X=\frac{(S 1 \times F 1)+(S 2 \times F 2)+(S 3 \times F 3)+(S 4 \times F 4)+(S 5+F 5)}{N} \\
\begin{array}{ll}
\text { Keterangan } \\
\text { X }
\end{array} \\
(S 5 \ldots . . S 1) & \begin{array}{l}
\text { : skor pada skala } 5 \text { sampai } 1 \\
\mathrm{~F}
\end{array} \\
& \begin{array}{l}
\text { : frekuensi jawaban pada satu } \\
\text { skala }
\end{array} \\
\mathrm{N} & \text { : sampel yang diolah }
\end{array}
$$

Untuk memposisikan jawaban responden tentang kepuasan terhadapa pelayanan perpustakaan digunakan skala interval yang menggambarkan posisi yang sangat negatif ke posisi yang sangat positif dengan rumus skala interval sebagai berikut.

$$
\text { Skala interval }\{a(m-n): b\}
$$

Keterangan

$$
\begin{array}{ll}
\mathrm{a} & =\text { Jumlah atribut } \\
\mathrm{m} & =\text { skor teritinggi } \\
\mathrm{n} & =\text { skor terendah } \\
\mathrm{b} & =\text { Jumlah skala penilaian yang ingin } \\
\text { dibentuk }
\end{array}
$$

skala interval yang didapat $\quad\{1(5-1): 5\}=$ 0.8

Sehingga diperoleh kriteria penilaian sebagai berikut

\begin{tabular}{|c|c|}
\hline Skala & Kategori Penilaian \\
\hline $4.25-5.04$ & Sangat Puas \\
\hline $3.43-4.23$ & Puas \\
\hline $2.62-3.42$ & Cukup Puas \\
\hline $1.81-2.61$ & Tidak Puas \\
\hline $1.00-1,80$ & Sangat Tidak Puas \\
\hline
\end{tabular}


HASIL DAN PEMBAHASAN

Akumulasi hasil jawaban responden dijabarkan melalui empat variabel, yaitu:

I. Tingkat kepuasan pemustaka terhadap koleksi perpustakaan

II. Tingkat Kepuasan pemustaka terhadap layanan Perpustakaan

III. Tingkat Kepuasan pemustaka terhadap petugas perpustakaan

IV. Tingkat kepuasan pemustaka terhadap sarana dan prasarana perpustakaan
$17.5 \%$ Puas dan 25\% menyatakan Cukup puas, $22.5 \%$ menyatakan tidak puas dan $22.5 \%$ sangat tidak puas. Hasil penelitian menunjukan bahwa nilai skor rata rata kepuasan yang ditunjukkan adalah 2.75. Skor ini diolah menggunakan skal likert. Skor berada dalam skala interval 2.62-3.42 yang menunjukkan bahwa kepuasan responden terhadap kelengkapan koleksi adalah cukup puas. Pada perpustakaan Puslitbangkan Budidaya

Tabel 1

AKUMULASI JAWABAN RESPONDEN

\begin{tabular}{|c|c|c|c|c|c|c|c|c|c|c|c|c|c|c|c|c|c|c|c|c|}
\hline \multirow{2}{*}{$\begin{array}{l}\mathbf{N} \\
\mathbf{O}\end{array}$} & \multirow{2}{*}{ Unsur Yang Dinilai } & \multicolumn{6}{|c|}{ Jawaban Responden } & \multicolumn{6}{|c|}{$\%$} & \multicolumn{6}{|c|}{ Score } & \multirow{2}{*}{ Mean } \\
\hline & & SP & $\mathbf{P}$ & CP & TP & STP & $J M L$ & SP & $\mathbf{P}$ & $\mathbf{C P}$ & TP & STP & JML & 5 & 4 & 3 & 2 & 1 & JML & \\
\hline 1. & Koleksi Perpustakaan & & & & & & & & & & & & & & & & & & & \\
\hline 1 & $\begin{array}{l}\text { Kelengkapan koleksi bahan } \\
\text { pustaka }\end{array}$ & 5 & 7 & 10 & 9 & 9 & 40 & 12,5 & 17,5 & 25,0 & 22,5 & 22,5 & 100 & 25 & 28 & 30 & 18 & 9 & 110 & 2,75 \\
\hline 2 & $\begin{array}{l}\begin{array}{l}\text { Kemutakhiran koleksi } \\
\text { bahan pustaka }\end{array} \\
\end{array}$ & 3 & 9 & 8 & 10 & 10 & 40 & 7,5 & 22,5 & 20,0 & 25,0 & 25,0 & 100 & 15 & 36 & 24 & 20 & 10 & 105 & 2,63 \\
\hline 3 & $\begin{array}{l}\text { Peny ususunan koleksi di } \\
\text { rak }\end{array}$ & 6 & 10 & 18 & 5 & 1 & 40 & 15,0 & 25,0 & 45,0 & 12,5 & 2,5 & 100 & 30 & 40 & 54 & 10 & 1 & 135 & 3,38 \\
\hline II. & Layanan Perpustakaan & & & & & & & & & & & & & & & & & & & \\
\hline 1 & Lay anan sirkulasi & 8 & 10 & 18 & 2 & 2 & 40 & 20,0 & 25,0 & 45,0 & 5,0 & 5,0 & 100 & 40 & 40 & 54 & 4 & 2 & 140 & 3,50 \\
\hline 2 & $\begin{array}{l}\text { Menerapkan sistim } \\
\text { pelay anan terbuka }\end{array}$ & 8 & 14 & 14 & 2 & 2 & 40 & 20,0 & 35,0 & 35,0 & 5,0 & 5,0 & 100 & 40 & 56 & 42 & 4 & 2 & 144 & 3,60 \\
\hline 3 & $\begin{array}{l}\text { Kemudahan penelusuran } \\
\text { inf omasi }\end{array}$ & 9 & 10 & 15 & 4 & 2 & 40 & 22,5 & 25,0 & 37,5 & 10,0 & 5,0 & 100 & 45 & 40 & 45 & 8 & 2 & 140 & 3,50 \\
\hline 4 & Pelay anan Foto copy & 2 & 3 & 17 & 13 & 5 & 40 & 5,0 & 7,5 & 42,5 & 32,5 & 12,5 & 100 & 10 & 12 & 51 & 26 & 5 & 104 & 2,60 \\
\hline III. & $\begin{array}{l}\text { Petugas Perpustakaan } \\
\text { (Pustakawan) }\end{array}$ & & & & & & & & & & & & & & & & & & & \\
\hline 1 & $\begin{array}{l}\text { Memberikan pelay anan } \\
\text { y ang cepat dan tepat }\end{array}$ & 8 & 10 & 18 & 2 & 2 & 40 & 20,0 & 25,0 & 45,0 & 5,0 & 5,0 & 100 & 40 & 40 & 54 & 4 & 2 & 140 & 3,50 \\
\hline 2 & Keramahan petugas & 7 & 13 & 16 & 2 & 2 & 40 & 17,5 & 32,5 & 40,0 & 5,0 & 5,0 & 100 & 35 & 52 & 48 & 4 & 2 & 141 & 3,53 \\
\hline 3 & $\begin{array}{l}\text { Wawasan pengetahuan } \\
\text { petugas dalam membantu } \\
\text { mencari informasi }\end{array}$ & 10 & 15 & 6 & 5 & 4 & 40 & 25,0 & 37,5 & 15,0 & 12,5 & 10,0 & 100 & 50 & 60 & 18 & 10 & 4 & 142 & 3,55 \\
\hline 4 & Bimbingan pada pemustaka & 11 & 20 & 7 & 1 & 1 & 40 & 27,5 & 50,0 & 17,5 & 2,5 & 2,5 & 100 & 55 & 80 & 21 & 2 & 1 & 159 & 3,98 \\
\hline IV. & Sarana dan Prasarana & & & & & & & & & & & & & & & & & & & \\
\hline 1 & $\begin{array}{l}\text { Sarana komputer } \\
\text { penelusuran on line }\end{array}$ & 2 & 4 & 14 & 15 & 5 & 40 & 5,0 & 10,0 & 35,0 & 37,5 & 12,5 & 100 & 10 & 16 & 42 & 30 & 5 & 103 & 2,58 \\
\hline 2 & Akses jaringan internet & 13 & 15 & 9 & 2 & 1 & 40 & 32,5 & 37,5 & 22,5 & 5,0 & 2,5 & 100 & 65 & 60 & 27 & 4 & 1 & 157 & 3,93 \\
\hline 3 & $\begin{array}{l}\text { Kondisi lemari,meja dan } \\
\text { kursi }\end{array}$ & 9 & 8 & 14 & 6 & 3 & 40 & 22,5 & 20,0 & 35,0 & 15,0 & 7,5 & 100 & 45 & 32 & 42 & 12 & 3 & 134 & 3,35 \\
\hline 4 & Kenyamanan ruangan & 5 & 13 & 14 & 5 & 3 & 40 & 12,5 & 32,5 & 35,0 & 12,5 & 7,5 & 100 & 25 & 52 & 42 & 10 & 3 & 132 & 3,30 \\
\hline
\end{tabular}

SP:Sangat Puas P:Puas

TP: Tidak Puas STP : Sangat Tidak Puas

ANALISA DATA PENELITIAN

\section{Tingkat kepuasan terhadap koleksi perpustakaan}

\section{1 Tingkat kepuasan terhadap kelengkapan koleksi}

Berdasarkan pada tabel 1 perihal tingkat kepuasan terhadap kelengkapan koleksi, responden menyatakan $12.5 \%$ sangat puas, 118

$$
\text { CP: Cukup Puas }
$$

\section{I.2. Tingkat kepuasan terhadap kemutakhiran koleksi}

Berdasarkan pada tabel 1 perihal kemutakhiran koleksi, responden $12.5 \%$ menyatakan sangat puas, $17.5 \%$ menyatakan puas dan $25 \%$ cukup puas, $22.5 \%$ menyatakan tidak puas dan $22.5 \%$ menyatakan sangat tidak puas. Hasil penelitian menunjukan bahwa nilai skor rata rata kepuasan yang ditunjukkan adalah 2.63. 
Skor ini diolah menggunakan skala likert. Skor berada dalam skala interval 2.62-3.42 yang menunjukkan bahwa kepuasan responden terhadap kelengkapan koleksi adalah Tidak

Puas terhadap kelengkapan koleksi pada perpustakaan Puslitbangkan Budidaya.

Kemutakhiran sangat diperlukan dalam koleksi perpustakaan, terlebih bagi perpustakaan khusus dimana peneliti sangat membutuhkan informasi terbaru sebagai pengembangan wawasan dan penelitiannnya. Untuk memenuhi kebutuhan informasi tersebut perlunya diadakan pengadaan koleksi secara rutin per tahun. Dalam pengadaan koleksi menurut Lasa, HS (2005) perlu mempertimbangkan (a) relevansi, kesesuian koleksi dengan keperluan pemustaka agar koleksi perpustakaan memiliki nilai dan berdaya guna bagi pemustaka; (b) kemutakhiran, dalam pengembangan koleksi perlu antisipatif dengan perkembangan ilmu pengetahuan dan bidang cakupan perpustakaan itu sendiri; (c) rasio judul, pemakai dan spesialis bidang; (d) tidak bertentangan dengan politik, ideologi, agama/keyakinan, ras, maupun golongan; (e) kualitas, koleksi yang direncanakan hendaknya memenuhi syarat-syarat kualitas yang ditentukan, misalnya berkaitan dengan subjek, reputasi pengarang, dan reputasi penerbit; (f) objek keilmuan, koleksi suatu perpustakaan itu signifikan dengan visi, misi dan tujuan lembaga induknya. Tujuan perpustakaan khusus menurut Hasugian (2009 : 82) adalah Perpustakaan yang hanya menyediakan koleksi khusus yang berkaitan dengan misi dan tujuan dari organisasi atau lembaga yang memilikinya dan biasanya hanya memberikan pelayanan yang khusus hanya kepada staf organisasi atau lembaganya saja

\section{Tingkat kepuasan terhadap layanan perpustakaan}

\section{II.1.Tingkat kepuasan terhadap layanan sirkulasi}

Berdasarkan tabel 1 perihal kepuasan terhadap layanan sirkulasi, responden $20 \%$ menyatakan sangat puas, $25 \%$ puas, $45 \%$ cukup puas, $5 \%$ tidak puas dan $5 \%$ sangat tidak puas. Hasil penelitian menunjukan bahwa nilai skor rata rata kepuasan yang ditunjukkan adalah 3.5. Skor ini diolah menggunakan skala likert. Skor berada dalam skala interval 3.434.23 yang menunjukkan bahwa kepuasan responden terhadap terhadap layanan sirkulasi adalah Puas terhadap pelayan sirkulasi di perpustakaan Puslitbangkan Budidaya

Pelayanan sirkulasi merupakan ujung tombak kegiatan perpustakaan dimana pada bagian inilah tempat berinteraksi antara pustakawan dengan pemustaka dalam mencari kebutuhan informasinya, menurut Sutarno (2006: 90) Layanan perpustakaan merupakan salah satu kegiatan utama disetiap perpustakaan dimana layanan tersebut merupakan kegiatan yang langsung berhubungan dengan masyarakat dan sekaligus merupakan barometer keberhasilan perpustakaan.

\section{II.2.Tingkat kepuasan sistim pelayanan terbuka}

Berdasarkan tabel.1 perihal penerapan sistim pelayanan terbuka, responden menyatakan $20 \%$ sangat puas, $35.00 \%$ puas, $35.00 \%$ cukup puas $5 \%$ tidak puas, dan $5 \%$ sangat tidak puas. Hasil penelitian menunjukan bahwa nilai skor rata rata kepuasan yang ditunjukkan adalah 3.60 Skor ini diolah menggunakan skala likert. Skor berada dalam skala interval 3.43-4.23 yang menunjukkan bahwa kepuasan responden terhadap kelengkpan koleksi adalah Puas. Berdasarkan perolehan kurang dari setengah (35\%), responden merasa Puas terhadap sistim pelayanan terbuka yang diterapkan perpustakaan Puslitbangkan Budidaya. Dalam pelayanan sistim terbuka pemustaka dapat langsung memilih sendiri bahan pustaka di rak sehingga memungkinkan kesalahan penempatan koleksi kembali oleh pemustaka, Sebagaimana pendapat Darmono (2001: 139) kerugian sistem layanan terbuka antara lain: 1).Ada kemungkinan pengaturan buku di rak penempatan (jajaran), tenjadi kacau karena ketika mereka melakukan browsing.2). Buku yang sudah dicabut dari jajaran rak dikembalikan lagi oleh pemakai secara tidak tepat.3). Ada kemungkinan buku yang hilang relatif lebih besar bila dibandingkan dengan 
sistem yang bersifat tertutup. 4).Memerlukan ruangan yang lebih luas untuk jajaran koleksi agar lalu lintas/mobilitas pemakai lebih leluasa, 5)Membutuhkan keamanan yang lebih. Sistem pelayan terbuka memilih koleksi sesuai dengan keinginannnya, Demikian pula pendapat Sulistiyo Basuki (1991: 75) sistim terbuka (open acces pemustaka dapat memilih dan mengambil koleksi di rak secara bebas tanpa melalui pemustaka.

\section{II.3.Tingkat kepuasan terhadap penelusuran informasi}

Berdasarkan tabel 1 perihal kemudahan penelusuran informasi, responden $22.5 \%$ menyatakan sangat puas, $25 \%$ puas, 37.5\% cukup puas, $10 \%$ tidak puas dan $5 \%$ sangat tidak puas. Hasil penelitian menunjukan bahwa nilai skor rata rata kepuasan yang ditunjukkan adalah 3.5. Skor ini diolah menggunakan skala likert. Skor berada dalam skala interval 3.434.23 yang menunjukkan bahwa kepuasan responden terhadap penelusuran informasi adalah Puas pada perpustakaan Puslitbangkan Budidaya

\section{II.4.Tingkat kepuasan layanan fotocopy}

Berdasarkan tabel 1 perihal pelayanan fotocopy, responden $5 \%$ menyatakan sangat puas, $7.5 \%$ puas, $42.5 \%$ cukup puas, $32.5 \%$ tidak puas dan $12.5 \%$ sangat tidak puas. Hasil penelitian menunjukan bahwa nilai skor rata rata kepuasan yang ditunjukkan adalah 2.61. Skor ini diolah menggunakan skala likert. Skor berada dalam skala interval 1.81-2.61yang menunjukkan bahwa kepuasan responden terhadap pelayanan fotocopy adalah Tidak Puas pada perpustakaan Puslitbangkan Budidaya

Fasilitas dan peralatan merupakan salah satu komponen yang sangat penting dalam proses layanan perpustakaan, Sebagaimana yang dikemukakan oleh Rahayuningsih (2007:86) bahwa fasilitas merupakan segala hal yang memudahkan suatu kegiatan dan kelancaran tugas, seperti gedung, perlengkapan (meja, kursi, rak dan sebagainya). Karena tanpa adanya fasilitas yang memadai baik dari segi kualitas maupun kuantitas tentunya kegiatan layanan sulit untuk berjalan sebagai mana mestinya

\section{Tingkat kepuasan terhadap petugas perpustakaan}

\section{III.1 Tingkat kepuasan pada pelayanan yang cepat dan tepat}

Berdasarkan tabel 1 perihal pelayanan fotocopy, responden $20 \%$ menyatakan sangat puas, $25 \%$ puas, $45 \%$ cukup puas, $5 \%$ tidak puas dan $5 \%$ sangat tidak puas. Hasil penelitian menunjukan bahwa nilai skor rata rata kepuasan yang ditunjukkan adalah 3.5. Skor ini diolah menggunakan skala likert. Skor berada dalam skala interval 3.43- 4.23 yang menunjukkan bahwa kepuasan responden terhadap pelayanan petugas secara cepat dan tepat adalah Puas pada perpustakaan Puslitbangkan Budidaya

Berkaitan dengan pelayanan cepat dan tepat, menurut Dwijati (2006: 58) bahwa: Perpustakaan dikatakan baik, jika perpustakaan memiliki beberapa kriteria antara lain adalah: (1) koleksi yang relevan, aktual dan akurat, (2) tenaga yang berkualitas dan profesional, (3) sistem pelayanan yang cepat dan tepat, (4) didukung oleh sarana dan prasarana yang memadai. Selanjutnya perpustakaan dikatakan berhasil jika perpustakaan itu dimanfaatkan secara optimal oleh penggunanya.

\section{III.2. Tingkat kepuasan terhadap keramahan petugas}

Berdasarkan tabel.1 perihal keramahan petugas, responden $17.5 \%$ menyatakan sangat puas, $32.5 \%$ puas, $40 \%$ cukup puas, $5 \%$ tidak puas dan $2.5 \%$ sangat tidak puas. Hasil penelitian menunjukan bahwa nilai skor rata rata kepuasan yang ditunjukkan adalah 3.53. Skor ini diolah menggunakan skala likert. Skor berada dalam skala interval 3.43- 4.23 yang menunjukkan bahwa kepuasan responden terhadap keramahan petugas adalah Puas pada perpustakaan Puslitbangkan Budidaya. 
III. 3. Tingkat kepuasan terhadap wawasan petugas dalam pencarian informasi

Berdasarkan tabel.1 perihal wawasan petugas dalam pencarian informasi, responden menyatakan $25 \%$ sangat puas, $37.5 \%$ puas, $15 \%$ cukup puas, $12.5 \%$ tidak puas dan $10 \%$ menyatakan sangat tidak puas. Hasil penelitian menunjukan bahwa nilai skor rata rata kepuasan yang ditunjukkan adalah 3.55. Skor ini diolah menggunakan skala likert. Skor berada dalam skala interval 3.43- 4.23 yang menunjukkan bahwa kepuasan responden terhadap wawasan petugas dalam pencarian informasi adalah Puas pada perpustakaan Puslitbangkan Budidaya

Pustakawan harus mampu dalam mencari informasi alternatif pengganti yang sesuai apabila informasi yang dicari tidak ada atau tidak diketemukan sehingga pemustaka tetap terpenuhi kebutuhannya, dalam definisi pustakawan menurut UU No 43/2007 adalah seorang yang memiliki kompetensi yang diperoleh melalui pendidikan dan atau pelatihan kepustakawanan serta mempunyai tugas dan tanggungjawab untuk melaksanakan pengelolaan dan pelayanan perpustakaan.

\section{4.Tingkat kepuasan terhadap bimbingan pemustaka}

Berdasarkan tabel.1 perihal bimbingan kepuasan terhadap pemustaka, responden menyatakan $27.5 \%$ sangat puas, $50.0 \%$ puas, $17.5 \%$ cukup puas, $2.5 \%$ tidak puas dan $2.5 \%$ menyatakan sangat tidak puas. Hasil penelitian menunjukan bahwa nilai skor rata rata kepuasan yang ditunjukkan adalah 3.98. Skor ini diolah menggunakan skala likert. Skor berada dalam skala interval 3.43- 4.23 yang menunjukkan bahwa kepuasan responden terhadap wawasan petugas dalam pencarian informasi adalah Puas pada perpustakaan Puslitbangkan Budidaya

\section{Tingkat kepuasan sarana dan prasarana}

\section{IV.1. Tingkat kepuasan pemustaka terhadapan kesediaan komputer penelusuran}

Berdasarkan tabel.1 perihal tingkat kepuasan pemustaka terhadapan kesediaan komputer penelusuran, responden menyatakan
$5 \%$ sangat puas, $10 \%$ puas, $35 \%$ cukup puas, 37.5 tidak puas dan $12.5 \%$ menyatakan sangat tidak puas. Hasil penelitian menunjukan bahwa nilai skor rata rata kepuasan yang ditunjukkan adalah 2.56. Skor ini diolah menggunakan skala likert. Skor berada dalam skala interval 1.81-2.61 yang menunjukkan bahwa kepuasan responden terhadap wawasan petugas dalam pencarian informasi adalah Tidak Puas pada perpustakaan Puslitbangkan Budidaya

Di era teknologi informasi semua aktifitas berjalan cepat demikian pula perpustakaan khususnya dalam penelusuran informasi, penelusuran informasi melalui online public acces computer dapat menghasilkan penelusuran yang lebih cepat, tepat dan akurat dan pastinya lebih efisien dari segi waktu dan tenaga sebagaimana menurut Nugraha, AS (2004:5) Dampak teknologi informasi secara umum terhadap kehidupan bermasyarakat antara lain meningkatkan standar dan efisiensi kehidupan. Teknologi informasi dapat menghemat waktu, tenaga, meningkatkan hasil dan pengembangan produk. Pendapat tersebut sejalan dengan Suharto, Adib dalam materi kursus Pengantar Otomasi Perpustakaan (1997:3) yang menyatakan bahwa penerapan otomasi perpustakaan dimaksudkan untuk meningkatkan produktivitas dan efektivitas kegiatan rumah tangga perpustakaan dan berorientasi tidak hanya kepada kepentingan pustakawan tetapi juga kepentingan pemakai perpustakaan.

Salah satu bagian penting yang menjadi hal yang tak terpisahkan dari seluruh perpustakaan adalah proses temu kembali informasi, dimana secara spesifik juga akan menyangkut layanan yang secara online.

\section{IV.2.Tingkat kepuasan terhadap ketersediaan jaringan internet}

Berdasarkan tabel.1 perihal kepuasan terhadap ketersediaan jaringan internet responden menyatakan $13 \%$ sangat puas, 15 $\%$ puas, $9 \%$ cukup puas, $2 \%$ tidak puas dan 1 $\%$ menyatakan sangat tidak puas. 
Hasil penelitian menunjukan bahwa nilai skor rata rata kepuasan yang ditunjukkan adalah 3.925. Skor ini diolah menggunakan skala likert. yang menunjukkan bahwa kepuasan responden terhadap jaringan intenet adalah Puas pada perpustakaan Puslitbangkan Budidaya

Tabel 2.

\section{REKAPITULASI KEPUASAN PEMUSTAKA PADA PELAYANAN PERPUSTAKAAN PUSLITBANG PERIKANAN BUDIDAYA}

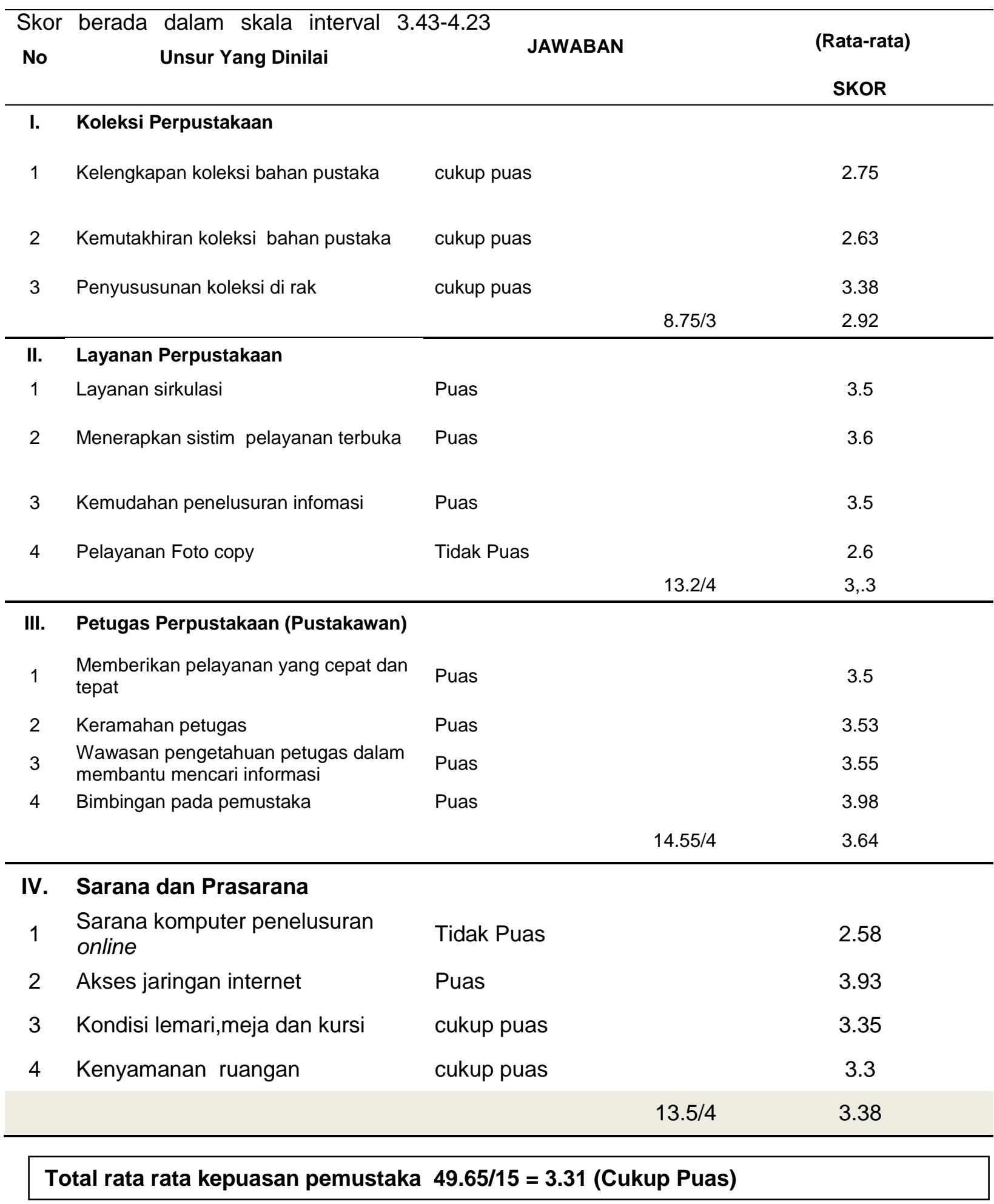




\section{IV.3.Tingkat kepuasan pemustaka terhadap fasilitas peralatan perpustakaan}

Berdasarkan tabel 1 perihal kepuasan fasilitas peralatan perpustakaan, responden menyatakan $22.5 \%$ sangat puas, $20 \%$ puas, $35 \%$ cukup puas, $25 \%$ tidak puas dan $7.5 \%$ menyatakan sangat tidak puas. Hasil penelitian menunjukan bahwa nilai skor rata rata kepuasan yang ditunjukkan adalah 3.35. Skor ini diolah menggunakan skala likert. Skor berada dalam skala interval 2.62-3.42 yang menunjukkan bahwa kepuasan responden terhadap fasilitas peralatan perpustakaan adalah Puas pada perpustakaan Puslitbangkan Budidaya

Fasilitas perpustakaan merupakan perabotan dan peralatan yang harus ada di perpustakaan sepert meja-kursi, kerja layanan, berbagai rak, berbagai lemari dan jenis laci, komputer, printer, scanner, mesin foto kopi, alat baca mikro dan lain-lain. Keterlibatan pustakawan sangat diperlukan dalam penentuan kebutuhan yang sesuai dengan perpustakaan

\section{IV.4. Tingkat kepuasan terhadap kenyaman perpustakaan}

Berdasarkan tabel.1 perihal kepuasan terhadap kenyaman perpustakaan responden menyatakan $12.5 \%$ sangat puas, $32.5 \%$ puas, $35 \%$ cukup 12.5 tidak puas dan $7.5 \%$ sangat tidak puas menunjukan bahwa nilai skor rata

rata kepuasan yang ditunjukkan adalah . 3.3. Skor ini diolah menggunakan skala likert. Skor berada dalam skala interval 2.62-3.42 yang menunjukkan bahwa kepuasan responden terhadap kenyamanan perpustakaan Cukup Puas pada perpustakaan Puslitbangkan Budidaya

Hasil rekapitulasi pada tabel 2 menunjukkan variabel mengenai kepuasan koleksi perpustakaan diketahui bahwa skor rata rata adalah 2.92 dengan demikian dapat disimpulkan bahwa tingkat terhadap kepuasan pemustaka terhadap koleksi perpustakaan Puslitbang Perikanan Budidaya Cukup Puas karena terdapat pada skala interval 2.62-3.42. Pada variabel mengenai kepuasan terhadap layanan perpustakaan diketahui bahwa skor rata rata adalah 3.3 dengan demikian dapat disimpulkan bahwa tingkat kepuasan terhadap sirkulasi perpustakaan Puslitbang Perikanan Budidaya Cukup Puas karena berada pada skala interval 2.62-3.42. Pada variabel mengenai kepuasan terhadap petugas perpustakaan diketahui bahwa skor rata rata adalah 3.64 dengan demikian dapat disimpulkan bahwa tingkat kepuasan terhadap sirkulasi perpustakaan Puslitbang Perikanan Budidaya adalah Puas karena berada pada skala interval 3.43-4.23. Pada variabel mengenai sarana dan prasarana perpustakaan diketahui bahwa skor rata rata adalah 3.38 dengan demikian dapat disimpulkan bahwa tingkat kepuasan terhadap sirkulasi perpustakaan Puslitbang Perikanan Budidaya Cukup Puas karena berada pada skala interval 2.62-3.42. Berdasarkan data diatas dapat disimpulkan bahwa tingkat kepuasan terhadap pelayanan pada perpustakaan Puslitbangkan Budidaya Cukup memenuhi kebutuhan walaupun terdapat beberapa kekurangan

\section{PENUTUP}

\section{Kesimpulan}

1. Tingkat Kepuasan pemustaka terhadap koleksi dinyatakan cukup puas, dengan skor rata rata 2.92 dengan posisi skor terdapat pada interval 2.62-3.42. Rician hasil skor dari 3 pertanyaan pada variabel ini yang tertinggi yaitu penyusunan koleksi di rak 3.38 (cukup puas), koleksi bahan pustaka skor 2.75 (cukup puas), dan kemutakhiran koleksi bahan pustaka dengan skor. 2.63 ( cukup puas) merupakan skor terendah dari variabel ini

2. Tingkat Kepuasan pemustaka terhadap layanan perpustakaan dinyatakan cukup puas, dengan skor rata rata 3.3 dengan posisi skor terdapat pada interval 2.62-3.42 Rician Hasil skor dari 4 pertanyaan pada variabel ini yang tertinggi adalah penerapkan sistim terbuka dengan skor 3.60 (puas), layanan sirkulasi dan kemudahan penelusuran informasi dengan 
skor sama besarnya yaitu 3.50 (puas), sedangkan pelayanan foto copy dengan skor 2.60 (tidak puas) merupakan skor terendah pada variabel ini

3. Tingkat Kepuasan pemustaka terhadap tenaga perpustakaan dinyatakan cukup puas, dengan skor rata rata 3.64 dengan posisi skor terdapat pada interval 3.43-4.23. Rician hasil skor dari 4 pertanyaan pada variabel ini yang tertinggi yaitu bimbingan pemustaka dengan skor 3.98 (puas), wawasan pengetahuan petugas dalam membantu mencari informasi 3.55 (puas), keramahan petugas dengan skor 3.53 (puas), dan memberikan layanan cepat dan tepat 3.50 (puas) merupakan skor yang terendah dalam variabel ini

4. Tingkat Kepuasan pemustaka sarana dan prasarana perpustakaan dinyatakan cukup puas, dengan skor rata rata 3.3, dengan posisi skor pada interval 2.62-3.42. Rician Hasil skor dari 4 pertanyaan pada variabel ini yang tertinggi yaitu akses jaringan internet dengan skor 3.93 (puas), kondisi lemari, meja dan kursi dengan skor 3.35 (puas), kenyamanan ruangan dengan skor 3.30 (puas), sedangkan sarana penelusuran online dengan skor 2.58 ( tidak puas) merupakan skor terendah pada variabel ini

\section{Saran}

1. Kelengkapan dan kemutakhiran koleksi agar ditingkatkan. Terdapat beberapa cara agar koleksi lebih lengkap dan mutakhir yaitu: pembelian dengan terlebih dahulu mendatanya sesuai prioritas, kerjasama dengan perpustakaan sejenis (tukar menukar, fotocopy), Pustakawan proaktif mencari lembaga lembaga yang dapat menyumbangkan koleksinya

2. Untuk layanan fotocopy disarankan agar perpustakaan mempunyai mesin fotocopy sendiri dengan mempertimbangkan keamanan koleksi, keefisienan waktu agar pemustaka tidak terlau lama menunggu fotocopy di luar perpustakaan

3. Untuk sarana dan prasarana khususnya sarana penelusuran komputer online segera disediakan, karena dapat mempercepat penelusuran secara tepat dan tepat disamping itu tidak mengganggu pekerjaan petugas/pustakawan karena komputer dipinjam untuk menelusur informasi

\section{DAFTAR PUSTAKA}

Arikunto, S., 2002. Prosedur Penelitian, Suatu Pendekatan Praktek, PT Rineka Cipta, Jakarta

Badan Standar Nasional RI, 2009, Standardisasi nasional Indonesia untuk perpustakaan khusus instansi pemerintah, Perpustakaan Nasional RI, Jakarta.

Basuki, Sulistyo. 1993, Pengantar IImu Perpustakaan, Gramedia, Jakarta

Darmono,2001. Manajemen Perpustakaan, Grasindo Eastwood, Jakarta

Darmono, 2007, Perpustakaan Sekolah: Pendekatan Suatu Aspek Manajemen dan Tata Kerja, Gramedia Widiasmara Indonesia, Jakarta

Dwijati, S., 2006, Upaya meningkatkan kualitas jasa layanan informasi di perpustakaan. Buletin Perpustakaan UNAIR Surabaya 1(2): 58-63.

Hasugian, Jonner, 2009. Dasar-Dasar IImu Perpustakaan dan Informasi. Medan: USU Press, Medan

Hermawan,Rachman \& Zulfikar Zen, 2006, Jenis-Jenis Pelayanan Informasi Perpustakaan: Referensi untuk Perpustakaan Sekolah, Gadjah Mada University Press, Yogyakarta

Kotler, P., 1999, Manajemen pemasaran di Indonesia. Edisi 1, Salemba Empat, Jakarta

Lasa, HS., 2005, Manajemen Perpustakaan, Gama Media, Yogyakarta

Nugraha, Aries Setya, 2004, Teknologi Informasi dan Komunikasi untuk SMP kelas VII, Erlangga, Jakarta 
Purnomowati, S., 2000, Mengukur kinerja perpustakaan. BACA 25(3\&4): 61-67.

Rahayuningsih, F., 2007, Pengelolaan

Perpustakaan, Graha IImu, Yogyakarta

Riyanto, Agus, dkk. 2004, Analisis Kualitas Jasa

Pelayanan Perpustakaan Pascasarjana

Universitas Gadjahmada Yogyakarta.

Berkala IImu Perpustakaan dan

Informasi. Vol. II No. 1.

Sugiyono, 2009, Metode Penelitian Kuantitatif Kualitatif dan R \& D. Cet. 8, Alfabeta, Jakarta

Sulistyo-Basuki. 1991. Pengantar IImu

Perpustakaan, Gramedia, Jakarta

Sulistyo-Basuki. 1993. Pengantar IImu perpustakaan, Gramedia, Jakarta

Suharto, Adib., 1997, Pengantar Otomasi Perpustakaan : Materi Kursus Perpustakaan PSKP Soegijapranata, Semarang

Sutarno, NS. 2006. Manajemen Perpustakaan Cet. 2, Sagung Seto, Jakarta

Suwarno, W, 2009, Psikologi Perpustakaan, Sagung Seto, Jakarta

Tjiptono, F., 2002, Manajemen Jasa, Andi Offset, Yogyakarta. 